\title{
キトサン/セリシン混合膜の作製と生成膜の特性
}

\author{
滋賀県東北部工業技術センター 三宅 肇・脇坂博之 \\ 滋賀県立大学工学部渡辺太郎・清水慶昭 \\ 宮城教育大学西川重和
}

\section{Preparation of Chitosan/Sericin Blend Membrane and the Characteristics of the Resulting Membrane}

\author{
Hajime Miyake $^{* 1}$, Hiroyuki Wakisaka ${ }^{* 1}$,Taro Watanabe ${ }^{* 2}$, Yoshiaki Shimizu*2, and \\ Shigekazu Nishikawa ${ }^{* 3}$
}
${ }^{* 1}$ North Eastern Industrial Research Center of Shiga Prefecture, 27-39 Mitsuyamotomachi, Nagahama, 526-0024, Japan
${ }^{* 2}$ School of Engineering, The University of Shiga Prefecture, 2500 Hassaka-cho, Hikone 522-8533, Japan
${ }^{* 3}$ Miyagi University of Education, 149 Aramaki-aza-Aoba, Aobaku, Sendai 980-0845, Japan

\begin{abstract}
Physical properties of uncrosslinked and crosslinked by ethyleneglycoldiglycidyl (EGDE) or polyethyleneglycoldiglycidyl (PGDE) sericin-chitosan blend membranes were investigated.

1. The surface of chitosan membrane was very smooth even after the treatment with aqueous sodium hydroxide. Those of uncrosslinked and crosslinked blend membranes were relatively flat before washing, but they were extremely uneven after washing with an alkaline solution.

2. With increasing sericin mixing ratio tensile stress increased whereas tensile strain decreased for uncrosslinked blend membrane. For crosslinked blend membrane by EGDE, both of tensile stress and tensile strain decreased. Tensile stress increased but tensile strain decreased for crosslinked blend membrane by PGDE $(n=4)$. Both values for crosslinked blend membrane by PGDE $(n=9)$ were equal or over to those of chitosan membrane.

3. The diffusion coefficient and permeability coefficient for an anionic dye (CI Acid Orange 7) into the blend membrane greatly increased. Those for the blend membrane crosslinked by PGDE of $n=4$ decreased whereas those values for the crosslinked blend membrane by PGDE of $n=9$ increased, because of the increase in the porosity by cleaning with an aqueous sodium hydroxide.
\end{abstract}

(Received 20 May, 2006 ; Accepted 14 August, 2006)

\section{1. 緒 言}

カニやエビなどの甲殼類や菌類の細胞壁などに含まれ るキチンおよびその脱アセチル化体であるキトサンは, 生分解性, 生体適合性, 多官能性を持ち, 医用材料の分 野などで応用研究がなされている. 初期の研究例では, キチンを糸, シート, スポンジおよびビーズ状で動物実 験に供し, 組織反応, 治療状況, 吸収過程などを検討し、 生体適合性の良い吸収性材料であることが確認されてい る[1]. キトサンはこれまでにドラッグデリバリーシステ ム (DDS) として, 製剤添加物(経口投与剂、直打用賊形剂, 崩壊剤など), 放出制御製剂あるいは難溶性薬物の溶解性 の改善などに広く用いられている.さらに, 小球体やマ イクロカプセルとして, 長時間にわたるホルモンの埋込
型放出制御型 DDSや除草剂のマイクロカプセル化として も活用されている $[2,3]$.

一方, 主成分がセリン, スレオニン, グリシンからな るシルクタンパクの一種セリシンは, 高吸湿性, 抗酸化 性, 紫外線吸収能など優れた特性や抗酸化作用, ガン抑 制，皮膚炎に対する生理的作用をもつことが報告されて おり, 化粧品添加物や食品分野での応用研究がなされて いる[4-7].これまでセリシンは製糸廃水や精練廃水とと もに廃棄されていたが, 現在では新たな抽出法が開発さ れ, 工業的に大量のセリシンを回収することが可能となっ ている. しかしながら, フィルムや膜に成形した場合, 乾燥状態で非常に脆く, 水分や熱の影響を受けやすいこ とから，積極的に使用するには多くの問題がある.

同じ絹タンパク質であるフィブロインとキトサンの混 
合膜は, 機械的性質や水蒸気透過性, 酸素透過性に優れ ており，傷部保護膜，人工皮膚などへの利用について研 究がなされている $[8]$. また, 我々はこれまでに PVA/セ リシン混合膜や高分子量セリシンのフィルム化を行い, その膜が吸水性高分子膜であることを報告している $[9$, $10]$.

そこで，セリシンを構造や物性の比較的明らかなキト サンとブレンドした混合膜および混合溶液中に橋かけ剤 を加えて橋かけ混合膜を作製し，その特性を明らかにす ることを目的に研究を行った。

\section{2. 実 験}

\section{1 試料}

キトサンは甲陽ケミカル株製 FM80(脱アセチル化度 85\%)を用いた。 セリシンはセーレン(株製, 重量平均分子 量 $\mathrm{Mw}=80,000$ を用いた。また, 酢酸は和光純薬工業(株)製 の試薬特級を用いた。橋かけ剂はAldrich Chemical Company, Inc.の Ethylene Glycol Diglycidyl Ether(以下 EGDEと略記) と Nagase Chemtex Corporation の Polyethylene Glycol Diglycidyl Ether(以下 PGDEと略記、n = 4, 9) を用いた。 これらの構造式を Fig. 1に示す. 透過実験の透 過モデル物質は，著者らが合成し精製した CI Acid Orange 7を用いた (Fig. 2).

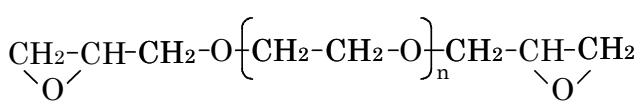

Fig. 1 Chemical structures of crosslinking agents. $\mathrm{n}=1$; etyleneglycoldiglycidylether (EDGE). $\mathrm{n}=4$, 9; polyethyleneglycoldiglycidylether (PGDE).

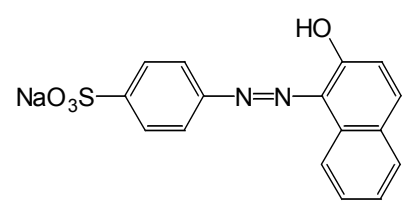

Fig. 2 Chemical structure of CI Acid Orange 7.

\section{2 セリシン/キトサン混合膜および橋かけ混合膜 の作製}

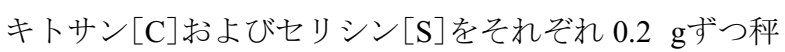
量し, 5 vol \% 䣷酸水溶液 $25 \mathrm{ml}$ に溶解して, $8 \times 10^{-3}(\mathrm{~g} / \mathrm{ml})$ の濃度とした。 また, キトサンとセリシンの全量を 100 と し, それらの混合割合を変化させて, 全濃度を $8 \times 10^{-3}$ $(\mathrm{g} / \mathrm{ml})$ とした．調製した溶液をテフロンバットに流し入れ， 室温で乾燥した後, 真空乾燥した。

橋かけ混合膜は次のように作製した。混合物に含まれ る全アミノ基 (ニンヒドリン試験から求めたキトサンおよ びセリシンのアミノ基含有量 $(\mathrm{mmol} / \mathrm{g})$ はそれぞれ 5.08 お よび0.198である.）に対して 0.5 当量となるように EGDE または $\operatorname{PGDE}(\mathrm{n}=4,9)$ を加え, 室温で 3 h撹挥した。これ
Table 1 Composition of the blend membrane and weight ratio of the crosslinking agent agsinst the weight of the blend membrane.

\begin{tabular}{cccccc}
\hline & キトサン(\%) & セリシン(\%) & $\mathrm{EGDE}(\mathrm{n}=1)$ & $\mathrm{PGDE}(\mathrm{n}=4)$ & $\mathrm{PGDE}(\mathrm{n}=9)$ \\
\hline $\mathrm{C}$ & 100 & 0 & 0.88 & 0.95 & 1.39 \\
CS9010 & 90 & 10 & 0.79 & 0.86 & 1.25 \\
CS8020 & 80 & 20 & 0.71 & 0.77 & 1.12 \\
CS7030 & 70 & 30 & 0.62 & 0.67 & 0.98 \\
CS5050 & 50 & 50 & - & 0.49 & 0.72 \\
CS3070 & 30 & 70 & - & 0.31 & 0.45 \\
CS2080 & 20 & 80 & - & 0.22 & 0.32 \\
\hline
\end{tabular}

らの溶液を前述と同様にテフロンバットに流し入れ, 室 温にて乾燥した後, 真空乾燥した。

膜はそれぞれ $4 \mathrm{wt} \% \mathrm{NaOH}$ 水溶液中に 3 時閒浸漬して洗 浄し, さらに蒸留水による洗浄を 30 分間, 3回繰り返した. 染料透過実験用膜は蒸留水に浸漬して保管した.

混合膜の組成と全混合物の質量に対する橋かけ剤の仕 込夕質量比を Table 1に示す. また, 橋かけの確認をする ため, $5 \mathrm{wt} \%$ 䣷酸に対する溶解試験も行った.

\section{3 FT-IRスペクトル, UVスペクトル}

FT-IRスペクトルおよびUVスペクトルの測定は，厚さ $10 \mu \mathrm{m}$ 程度の混合膜を作製し, $\mathrm{NaOH}$ 洗浄を行った後, ス チレンシャーレ上で真空乾燥した試料を用いた。 セリシ ン単独膜は, 水に溶解したセリシンを乾燥したものを用 いた，FT-IRスペクトルの測定は，株）日本分光製フーリエ 変換赤外分光光度計 FT-IR430を, UVスペクトルの測定は, (株)日立製作所製分光光度計 U-3000をそれぞれ用いた。

\section{4 質量損失率の測定}

作製した膜から $1.5 \mathrm{~cm}$ 角の試験片を切り出し, 真空乾 燥機で十分に乾燥したのち, 質量を精秤した。 $\mathrm{NaOH}$ 水溶 液で洗浄後, 水洗を行い, 再び真空乾燥機にて十分乾燥 したのち質量を精秤し, 洗浄前後の質量減少率を式(1) か ら算出した。

$$
\text { 質量減少率 }(\%)=\left(1-\mathrm{W}_{2} / \mathrm{W}_{1}\right) \times 100
$$

ここで， $\mathrm{W}_{1}$ は洗浄前の質量， $\mathrm{W}_{2}$ は洗浄後の質量である.

\section{5 原子間力顕微鏡 $(A F M)$ にる膜表面観察}

作製した混合膜および橋かけ混合膜の表面形状は，原 子間力顕微鏡 $(\mathrm{AFM})$ (Digital Instruments NANOSCOPEIII a) を用いて, タッピングモードで観察した。

\section{6 吸水性試験}

洗浄後の試験片を $30^{\circ} \mathrm{C}$ の蒸留水中(浴比 $1: 2000$ ) 24 hr浸漬した. 浸漬後, 膜の表面に付着している水をろ紙で 軽くふき取り, 各試料の質量を測定した. 吸水比は式(2) から算出した. 用いた膜は $\mathrm{NaOH}$ 水溶液で洗浄したもの である。

吸水比 $=\mathrm{W}_{2} / \mathrm{W}_{1}$

ここで, $\mathrm{W}_{1}$ は吸水前の質量, $\mathrm{W}_{2}$ は吸水後の質量である. 


\section{7 静的引張試験}

引張試験に供した混合膜は、洗浄後の膜の反りを抑え るため，ATTO侏製ゲルドライヤー RAPIDRY-MINI $\left(40^{\circ} \mathrm{C}\right.$, $10 \mathrm{~min}$ ) で吸引プレス乾燥し, 真空乾燥した。作製した混 合膜を幅 $3 \mathrm{~mm}$, 長さ $10 \mathrm{~mm}$ に切り出し, マイクロメータ で膜厚を測定後, KATO-TECH社製 KES-G3引張試験機を 用いて, 室温で引っ張り速度 $0.1 \mathrm{~mm} / \mathrm{s}$ で測定した。弾性 率は Stress-Strain曲線の初期勾配より求めた。橋かけを施 さない膜は未洗浄のものを, また橋かけ混合膜は $\mathrm{NaOH}$ 水溶液で洗浄したものを使用した.

\section{8 染料の吸着実験}

混合膜および橋かけ混合膜をそれぞれ $0.01 \mathrm{~g}$ 精秤し, $\mathrm{pH}$ 6.0の 0.1 M酢酸緩衝液にアニオン染料 CI Acid Orange 7 （以後， ORと略記）を溶解した溶液 $200 \mathrm{ml}$ 中に入れ， $30^{\circ} \mathrm{C}$ で $72 \mathrm{hr}$ 攪拌した。吸着後の染料溶液を紫外 - 可視分光光 度計を用い， $\lambda=485 \mathrm{~nm}$ において比色して遊離染料濃度を 求めた。 また, 染色した膜のホルムアミドによる処理 $(60$ $\left.{ }^{\circ} \mathrm{C}, 30 \mathrm{~min}\right)$ を, 6回繰り返して染料を完全に抽出し, 抽出 液を比色することにより, 膜に吸着した染料量を算出し た.

\section{9 染料の透過実験}

染料の透過実験には Fig. 3に示した装置を使用した。A 室 $(350 \mathrm{ml})$ と B室 $(70 \mathrm{ml}$ ) の接合部位（直径 $30 \mathrm{~mm}$ )を混合 膜で隔て，A室から B 室に染料が移行するように実験を 行った。所定時間毎に $\mathrm{A}$ 室および $\mathrm{B}$ 室から溶液を採取し， 可視・紫外分光光度計 (日立製作所製 1100 型)によって各 室の染料濃度を測定し, 求めた B 室の染料濃度から透過 染料量を決定した。透過実験はすべて $30^{\circ} \mathrm{C}$ の恒温槽中で 行った.

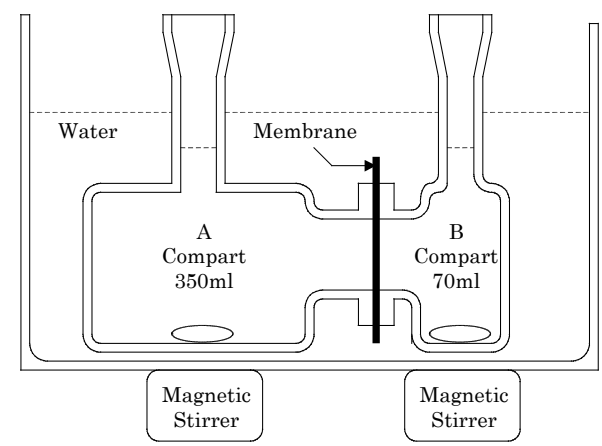

Fig. 3 Apparatus for the measurement of permeation against the dye.

\section{3. 結果および考察}

\section{1 橋かけおよびセリシンの存在の確認}

Fig. 4に NaOH洗浄後のキトサン橋かけ膜の IRスペクト ルを,また, Fig. 5に NaOH洗浄後の橋かけ混合膜 (CS8020) のIRスペクトルをそれぞれ示す、いずれの膜の場合にも $2870 \mathrm{~cm}^{-1}$ 付近にメチレン基に基づく強いピークみられる ことや(これは反応した橋かけ鼡に由来する.), さらに,
いずれの膜も 5 \%酶酸水溶液に溶解しなかったことから, 橋かけしていることが確認できた。

Fig. 6に, $\mathrm{NaOH}$ 洗浄後のキトサン単独膜, CS9010混合 膜, $\operatorname{CS} 9010(\mathrm{n}=4)$ 橋かけ混合膜の UVスペクトルを示寸. 混合膜について，セリシンに由来する $275 \mathrm{~nm}$ の゚ークが みられることから, $\mathrm{NaOH}$ 洗浄後にセリシンが残存してい ることが確認できる.

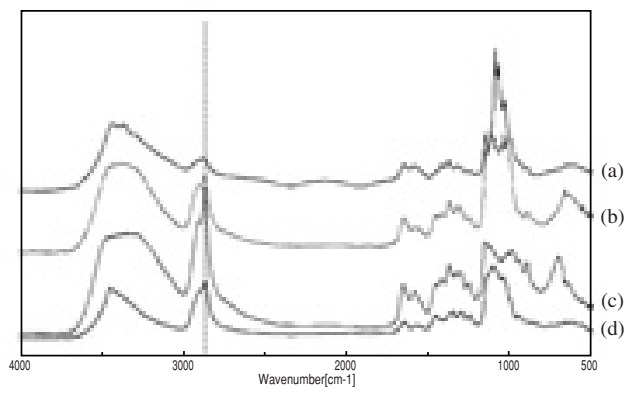

Fig. 4 FT-IR spectra for the chitosan membranes: (a), uncrosslinked; and crosslinked with; (b), EGDE; (c), PGDE ( $n=4)$; (d), PGDE ( $n=9)$.

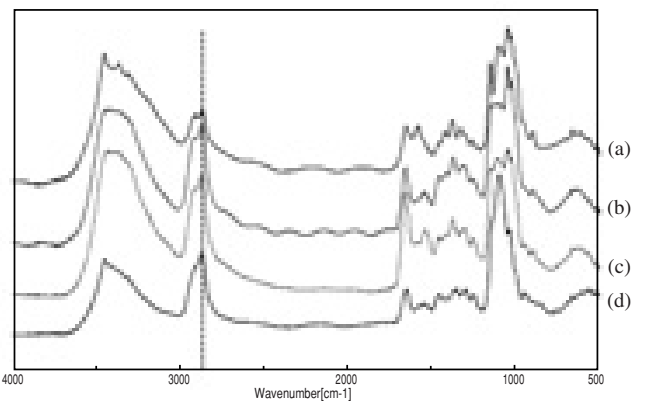

Fig. 5 FT-IR spectra for the blend membrane (CS8020): (a), uncrosslinked; and cross-linked with; (b), EGDE; (c), PGDE(n= 4); (d) PGDE(n=9).

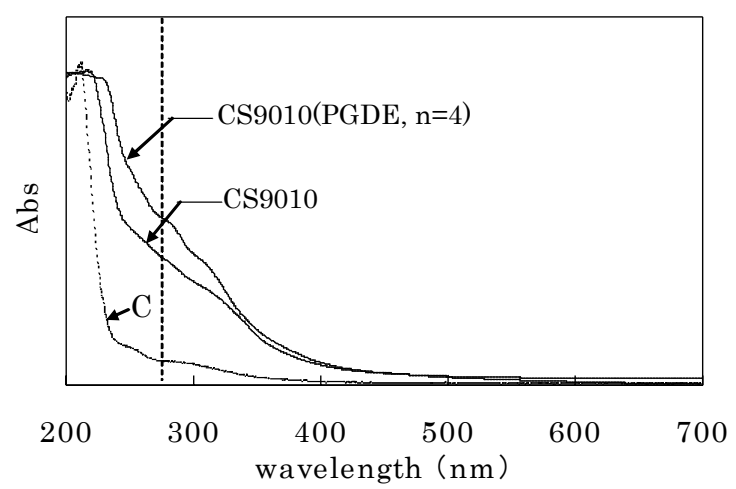

Fig. 6 UV spectra for the blend membrane and the cross linked blend membrane (CS9010).

\section{2 質量損失率}

Fig. 7 に混合膜および橋かけ混合膜の $\mathrm{NaOH}$ 洗浄による 質量損失率を示寸. $\mathrm{NaOH}$ 洗浄により, キトサン単独膜に おいて $13.9 \%$ の質量損失が確認された。これはキトサンを 溶解する際に用いた䣷酸アニオンが膜形成後も残存して おり，これが $\mathrm{NaOH}$ 洗浄により除去されるためである. 


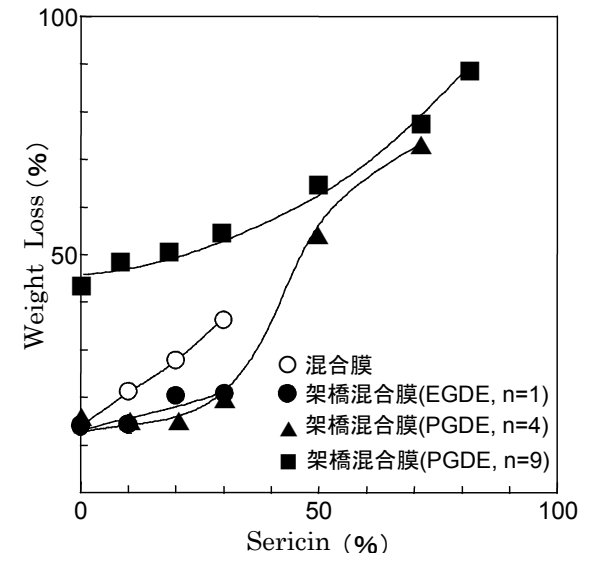

Fig. 7 Weight loss of the blend membrane and the cross linked blend membranes by cleaning with aqueous sodium hydroxide.

混合膜の場合には，セリシン成分の増加に伴い、質量損 失率が直線的に増加した。 セリシンはキトサンの約 $1 / 5$ の 分子量で, $\mathrm{NaOH}$ 水溶液に溶解することから, 混合膜の場 合の主な損失成分はセリシンおよび酢酸アニオンと考え られる.しかしながら, 前述のように FT-IRの結果（Fig. 5) から, 混合膜中にはなおセリシンが残存していることを 確認している.

橋かけ混合膜の質量損失率を検討すると, EGDEおよび $\operatorname{PGDE}(\mathrm{n}=4)$ で橋かけした場合, セリシンの混合割合が $30 \%$ までは混合膜よりも脱落が少なく, それ以上混合割合 が高くなると脱落も多くなる．これはセリシン中のアミ ノ基含有量がキトサンのアミノ含有量よりも極端に少な いため, セリシンの増加は橋かけ郕の反応率の低下につ ながるためと考えられる. PGDE $(\mathrm{n}=9)$ による橋かけ混合 膜は EGDEおよび $\operatorname{PGDE}(\mathrm{n}=4)$ による橋かけ混合膜より質 量損失率が高い。これは, 官能基間距離が長く, 橋かけ 効率が悪いためと考えられる.

\section{3 AFMIよよる表面顕微写真}

Fig. 8は, CS7030の未洗浄混合膜と洗浄混合膜の AFM による表面顕微写真の高低差イメージを示す，洗浄前の 膜表面 (a)が平坦であるのに対し, 洗浄後の膜表面(b)に

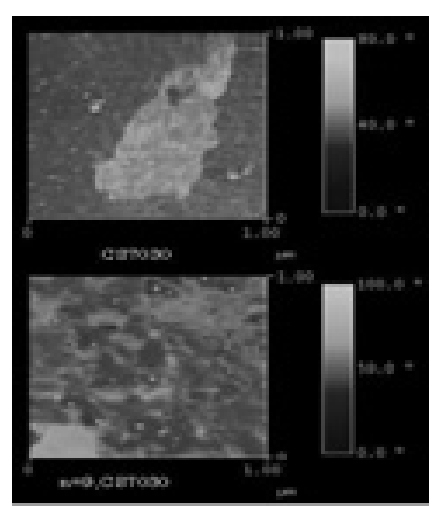

Fig. 10 AFM photograph of surface of chitosan membrane after cleaning with aqueous sodium hydroxide.

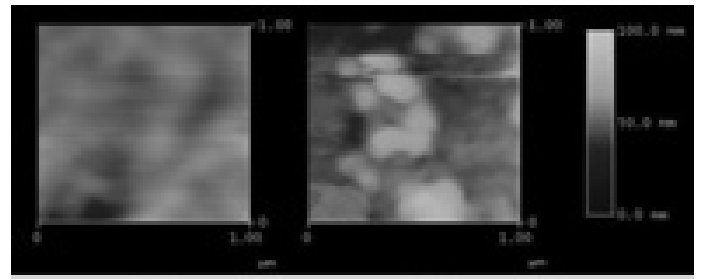

(a)

(b)

Fig. 8 AFM photographs of surface of blend membrane (CS7030); (a), Before $\mathrm{NaOH}$ treatment; (b), After $\mathrm{NaOH}$ treatment.

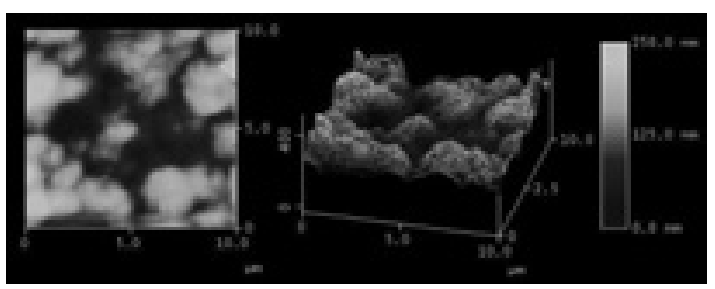

Fig. 9 AFM photograph of surface of cross linked blend membrane (CS7030) by PGDE ( $\mathrm{n}=9)$.

は約 $100 \mathrm{~nm}$ の凸が存在する.これは混在していたセリ シンの一部や酢酸アニオンが洗浄によって溶出したため と考えられる.また, $\operatorname{PGDE}(\mathrm{n}=9)$ による橋かけ混合膜 $(\mathrm{CS}$ 7030)においても，洗浄後は激しい凹凸が観察される (Fig. 9).これはセリシンの溶出に加えて, 未反応橋かけ剤が 溶出したためと考えられる. それに対して, 洗浄キトサ ン単独膜の起伏は最大でも $70 \mathrm{~nm}$ 程度であり (Fig. 10), 洗 浄に影響を受けることなく比較的平坦な形状をしている. Fig. 11に示す AFMの位相差イメージから, 混合膜および 橋かけ混合膜のキトサンとセリシンの分布を読みとるこ とができる. セリシンは写真において白色の点在した部 分と塊状の部分である。これはセリシンとキトサンには 相溶性がなく, 不均一に存在していることを示している. 一方, キトサン単独膜の位相差イメージから, キトサン はほぼ均一に分布していることがわかる (Fig. 10).

\section{4 吸水比}

混合膜および橋かけ混合膜の吸水比を測定した結果を Fig. 12に示す. 混合膜の吸水比はセリシンの混合割合の増

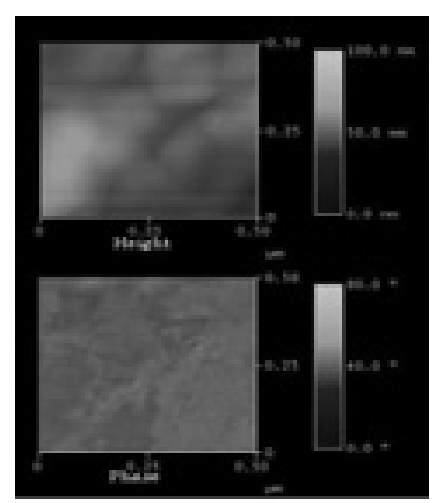

Fig. 11 Phase contrast image by AFM between the blend membrane and the cross linked blend membrane. 
加にともない高くなる. 混合割合が高くなると, $\mathrm{NaOH}$ 洗 浄によるセリシンの溶出量も多くなり, 膜がより多孔性 となるためと考えられる.

反応性が高く, 分子鎖の短い橋かけ剂 $\operatorname{PGDE}(\mathrm{n}=4)$ で 橋かけした混合膜では，セリシンの混合割合が $30 \%$ 以下 の場合, 橋かけによって膜が緻密な構造をとり, セリシ ンの溶出量も少ないので, 吸水比は低くてほぼ一定であ る。しかし, セリシン含有率が $50 \%$ 以上になると, セリ シンの溶出量が増えるため吸水比は増加する. また, PGDE (n = 9)による橋かけ混合膜の場合は, セリシンの混合割 合の増加につれて吸水比は高くなる.これには橋かけ部 分が長いため膜が柔軟になり, 分子間の間隙も広く, 未 反応成分の溶出によって生じた孔が多いからと考えられ る.

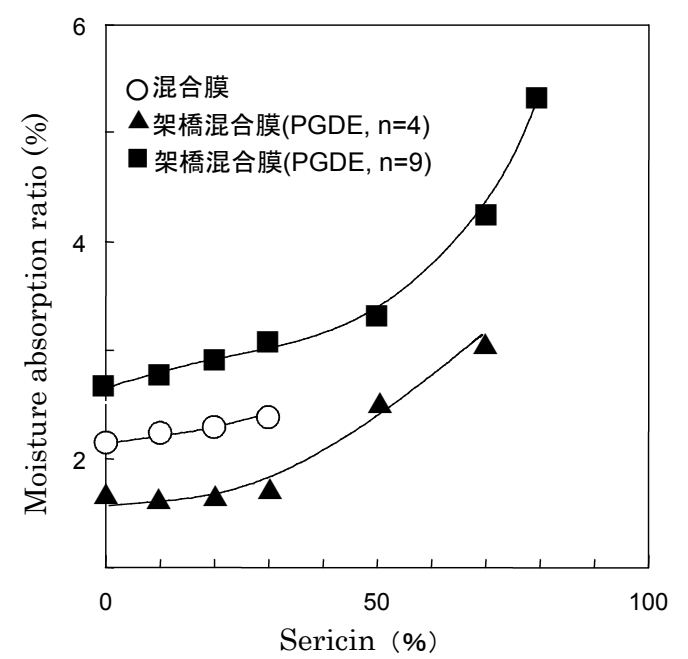

Fig. 12 Relation between the water absorbency and the sericin content mixed.

\section{5 静的引張試験}

Fig. 13に混合膜の応力ー歪み曲線を示す. セリシンの混 合割合が低い場合, 混合膜は十分な伸びを示す。しかし ながら, 混合割合の増加にともない硬くなり，伸びは極 端に減少する. セリシンの分子量がキトサンに比べて小 さいことやセリシン成分がキトサン相に均一に分散して いないことが原因であると考えられる.

Fig. 14に EGDEによる橋かけ混合膜の応力一歪み曲線を 示す，橋かけされたキトサン単独膜は未架橋の膜と比較 すると，その強度は増加したが伸びにくい性質を示した。 これは二官能性橋かけ剤である EGDEの長さが短いため に, 膜の柔軟性が低下したためと考えられる.また, EGDE で架橋された混合膜については, 応力, 歪みともに未架 橋の混合膜よりも低下し, その性質を改善することはで きなかった。

Fig. 15に PGDE $(n=4)$ による橋かけ混合膜の応力一歪み 曲線を示す. 橋かけされたキトサン単独膜は未架橋膜と 同等の歪みとそれを超える機械強度を示した.また, PGDE $(\mathrm{n}=4)$ 橋かけ混合膜は橋かけ部分が長くなるため, EGDE
を用いた場合に比べて応力は改善されるが, 延性におい てなお十分な值は得られなかった。これはキトサンとの 間で生じる架橋によって膜が緻密になることと, 不均一 に分散したセリシンによりその脆性が現れた結果である と考えられる.

Fig. 16に PGDE $(n=9)$ による橋かけ混合膜の応力一歪み

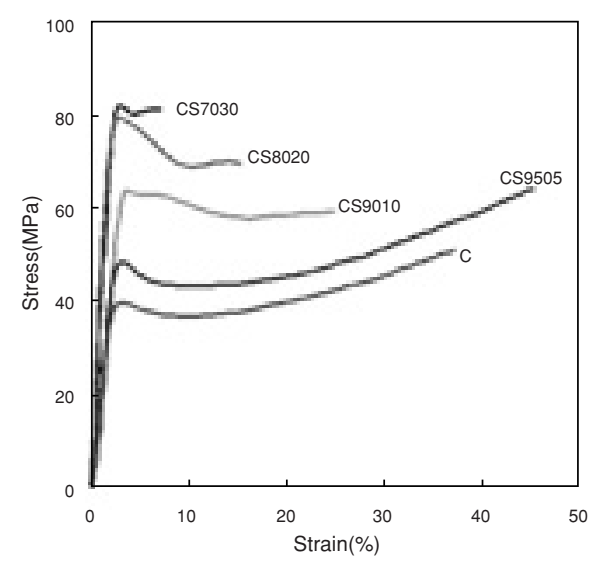

Fig. 13 Stress-Strain curve for blend membranes.

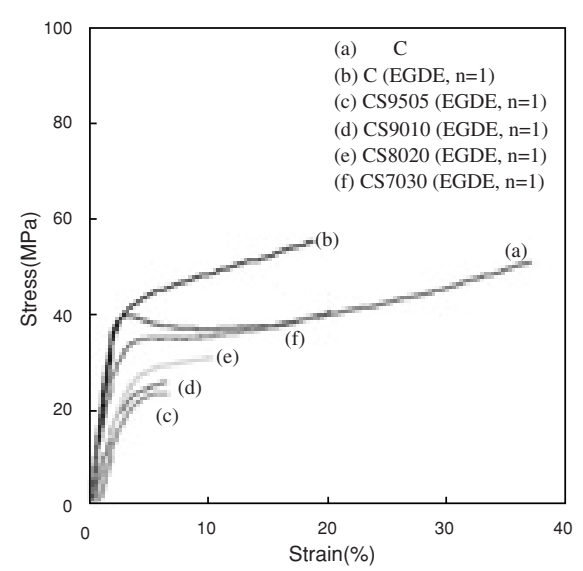

Fig. 14 Stress-Strain curve for cross linked blend membrane by EGDE.

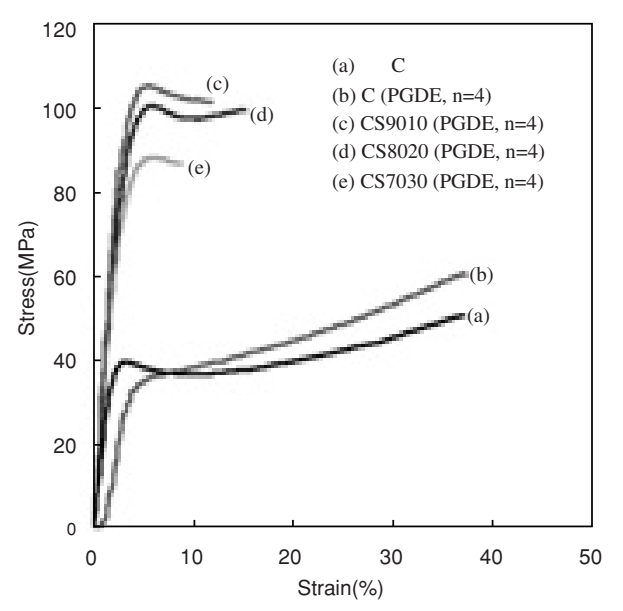

Fig. 15 Stress-Strain curve for the cross linked blend membrane by PGDE $(n=4)$. 
曲線を示す。橋かけされたキトサン単独膜, 混合膜は未 架橋の単独膜と比較して同等の歪みとそれを超える応力 を示す。これは分子鎖の長い架橋剤を用いることで，膜 構造に柔軟性が付与されたためと考えられる.

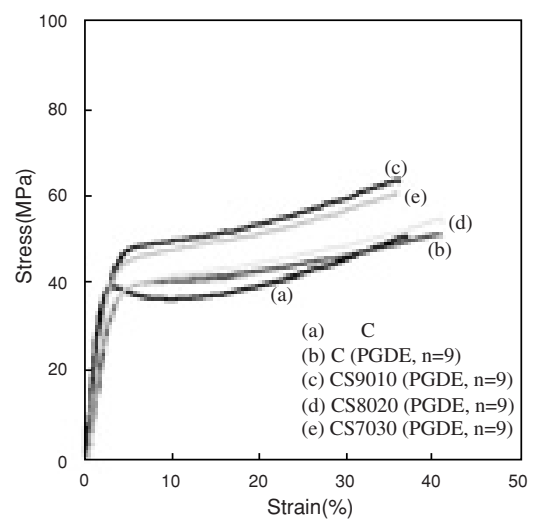

Fig. 16 Stress-Strain curve for the cross linked blend membrane by PGDE $(n=9)$.

\section{6 各種の膜に対する染料の吸着}

各種の膜に対するアニオン染料 ORの吸着挙動を $\mathrm{pH} 6.0$ において調べた。用いた膜はキトサン単独膜, 橋かけキ トサン膜, 混合膜, $\operatorname{PGDE}(\mathrm{n}=4)$ および $\operatorname{PGDE}(\mathrm{n}=9)$ で橋 かけした混合膜で，得られた吸着等温線を Fig. 17 (a), (b), (c) に示した.これらの膜に対するアニオン染料である OR の吸着は染料アニオンの膜中のプロトン化した塩基性基 への結合と考えられるから[11], その吸着は Langmuir型 である。そこで，吸着データに Scatchard 式を適用し[12], 各種の膜に対する染料の飽和吸着量を求めた。得られた 結果を Table 2に示す. これらの結果から，橋かけにより 吸着量が減少する傾向が見られる。これは橋かけ反応に より染料の結合座席である膜中の塩基性基の数が減少し たことに原因している．混合膜および橋かけ混合膜に対 する染料の吸着量には, キトサン単独膜, $\operatorname{PGDE}(\mathrm{n}=4,9)$ による橋かけキトサンと比較して大きな差異はなく, セ リシンの影響は見られなかった。 セリシンとキトサンの 混合段階で，全アミノ基に対するセリシンのアミノ基の 割合は最大でも $2 \%$ 未満であることを考慮すると, 染料吸
着へのセリシンの影響はほとんどなく，主にキトサンの アミノ基が吸着に関与していると考えられる.
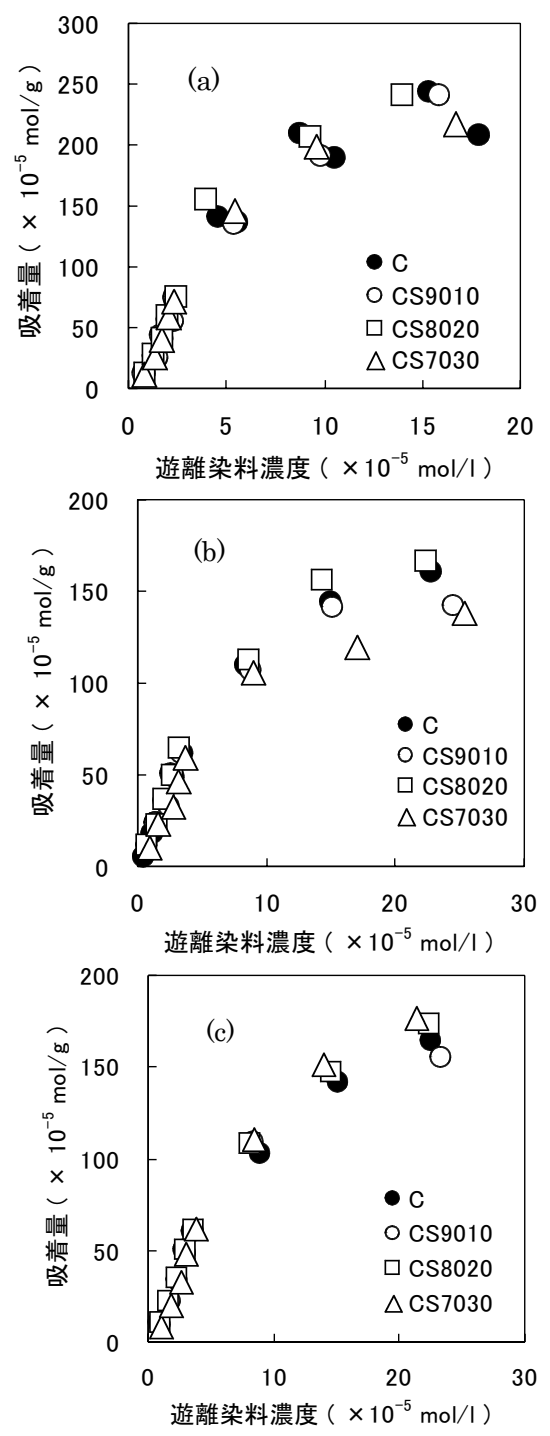

Fig. 17 Adsorption isotherms of CI Acid Orange 7 on the blend membrane and the cross linked blend membrane: (a), blend membrane; (b), cross linked blend membrane by $\operatorname{PGDE}(n=4) ;(c)$, cross linked blend membrane by $\operatorname{PGDE}(n=9)$.

Table 2 Saturation amounts of adsorption of dye on the blend membrane and cross linked blend membrane at $\mathrm{pH}$ 6.0: (a), blend membrane; (b), cross linked blend membrane by PGDE $(n=4)$; (c), cross linked blend membrane by PGDE $(n=9)$.

(a)

\begin{tabular}{cc}
\hline & $\begin{array}{c}\text { Saturation amounts } \\
\text { of adsorption of dye } \\
\left(\times 10^{-7} \mathrm{~mol} / \mathrm{g}\right)\end{array}$ \\
\hline $\mathrm{C}$ & 3.12 \\
$\mathrm{CS} 9010$ & 3.86 \\
$\mathrm{CS} 8020$ & 3.00 \\
$\mathrm{CS} 7030$ & 3.67 \\
\hline
\end{tabular}

(b)

\begin{tabular}{cc}
\hline & $\begin{array}{c}\text { Saturation amounts } \\
\text { of adsorption of dye } \\
\left(\times 10^{-7} \mathrm{~mol} / \mathrm{g}\right)\end{array}$ \\
\hline $\mathrm{C}$ & 2.35 \\
$\mathrm{CS} 9010$ & 1.83 \\
$\mathrm{CS} 8020$ & 2.46 \\
$\mathrm{CS} 7030$ & 1.77 \\
\hline
\end{tabular}

(c)

\begin{tabular}{cc}
\hline & $\begin{array}{c}\text { Saturation amounts } \\
\text { of adsorption of dye } \\
\left(\times 10^{-7} \mathrm{~mol} / \mathrm{g}\right)\end{array}$ \\
\hline $\mathrm{C}$ & 2.44 \\
$\mathrm{CS} 9010$ & 2.24 \\
$\mathrm{CS} 8020$ & 2.78 \\
$\mathrm{CS} 7030$ & 3.11 \\
\hline
\end{tabular}




\section{7 透過試験}

A室に OR 溶液 $\left(\mathrm{pH} 6.0,1.0 \times 10^{-4} \mathrm{~mol} / \mathrm{l}\right)$ を $350 \mathrm{ml} ， \mathrm{~B}$ 室に 緩衝溶液 $(\mathrm{pH} 6.0$, 電解質濃度 $0.1 \mathrm{~mol} / \mathrm{l}$ ) を $70 \mathrm{ml}$ 入れて透過 実験を行った。両室の染料濃度の経時変化と両室の染料 濃度差を透過時間に対してプロットした例(CS9010の場 合)を Fig. 18に示す. 時間変化にともない濃度差は次第に 小さくなり，B室への透過速度も小さくなっている。

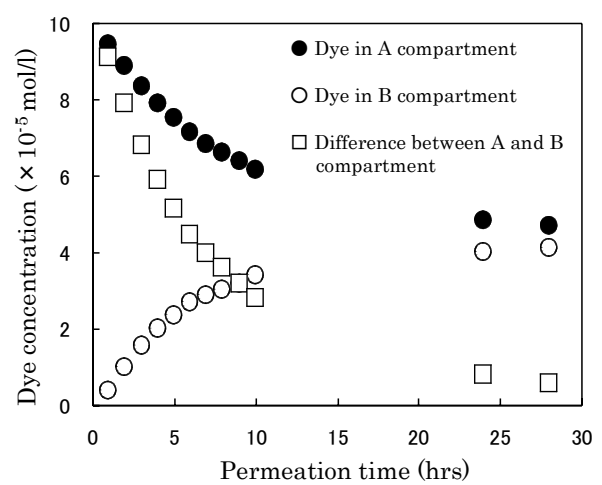

Fig. 18 Permeation of CI Acid Orange 7 through the blend membrane (CS9010) at $30^{\circ} \mathrm{C}$ and $\mathrm{pH}$ 6.0.

\subsection{1 遅れ時間法による拡散係数の決定}

拡散係数 $D$ と膜中の溶質が定常状態に達するまでの遅 れ時間 Lとの関係は、次式で表記される。

$$
\mathrm{D}=l^{2} / 6 \mathrm{~L}
$$

ここで, $l$ は膜の厚さである. B 室の染料濃度を透過時 間 $\mathrm{t}$ の平方根に対してプロットした図を Fig. 19に示す (CS 9010の場合).グラフはほぼ直線を示す，X軸との交点よ り遅れ時間 Lを決定し，式(3) から各混合膜中の染料の拡 散係数 Dを算出した.

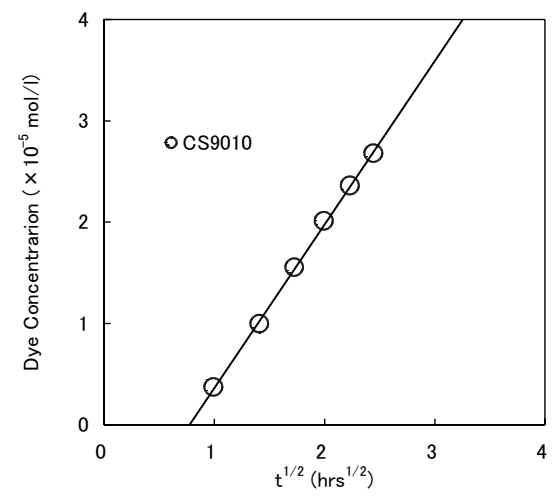

Fig. 19 Relation between the dye concentration in B compartment and $\mathrm{t}^{1 / 2}$.

\section{7.2 透過係数}

単位時間あたりに膜を透過する溶質の流れ $(\mathrm{J})$ は次式で 表される.

$$
\mathrm{J} / \mathrm{S}=\mathrm{Km}([\mathrm{A}]-[\mathrm{B}]) / l
$$

ここで, Sは膜の断面積, lは膜厚, $([A]-[B]) / l$ は濃度 勾配, $K m$ は透過係数である. 電解質濃度 $0.1 \mathrm{~mol} / 1, \mathrm{pH} 6.0$ の緩衝溶液中での単位時間あたりの膜を透過した染料量 の ORの平均濃度差に対するプロット(CS9010の場合)を Fig. 20に示す.このグラフはほぼ直線的関係にあるので, 式(4)を満たすと考えられる。この直線の勾配より透過係 数 $K m$ を算出した.

これらの式から求めた拡散係数 $D$, および透過係数 $\mathrm{Km}$ の值を Table 3に示す. 混合膜中の染料の拡散係数および 透過係数の值はセリシンの添加により非常に高くなる. これはキトサン単独膜が緻密で平坦な膜であるのに対し， 混合膜は $\mathrm{NaOH}$ 水溶液による洗浄によってセリシンの一 部が溶出し $[8]$, 混合膜中の孔 (pore)が増したためと考え られる。

$\operatorname{PGDE}(\mathrm{n}=4)$ による橋かけ混合膜中の拡散係数および透 過係数は未架橋混合膜中よりも低い值を示した。これは 分子鎖が短く反応性の高い橋かけ剂 $(\mathrm{n}=4)$ のため, $\mathrm{NaOH}$ 洗浄による溶出量が少なく, また橋かけにより膜が緻密

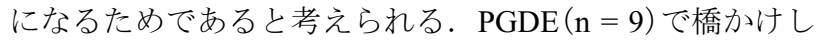
た混合膜は未架橋キトサン単独膜と比較して拡散係数, 透過係数ともに増加する傾向が見られる。これは未反応 橋かけ剂およびセリシンの一部の溶出による膜の多孔性 の増加によるものと考えられる.

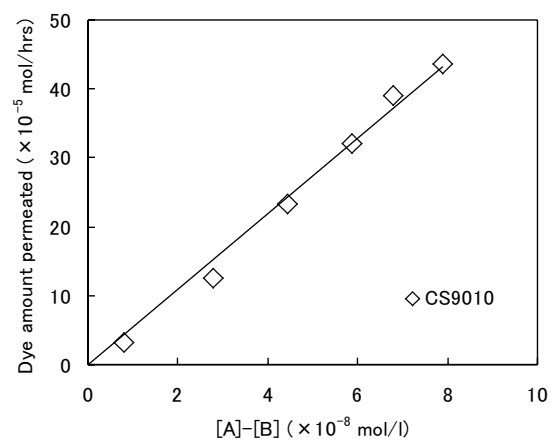

Fig. 20 Determination of permeation coefficient against CI Acid Orange 7.

Table 3 Diffusion coefficient (determined using time -

\begin{tabular}{|c|c|c|c|c|}
\hline & & $\begin{array}{l}\text { Diffusion } \\
\text { coefficient }\left(\mathrm{D}_{\mathrm{L}}\right) \\
\left(\times 10^{-7} \mathrm{~cm}^{2} / \mathrm{min}\right)\end{array}$ & $\begin{array}{l}\text { Permeability } \\
\text { coefficient }\left(\mathrm{K}_{\mathrm{m}}\right) \\
\left(\times 10^{-5} \mathrm{~cm}^{2} / \mathrm{min}\right)\end{array}$ & $\begin{array}{l}\text { Membrane } \\
\text { thickness } \\
(\mathrm{mm})\end{array}$ \\
\hline \multirow{4}{*}{$\begin{array}{l}\text { Blended } \\
\text { membrane }\end{array}$} & C & 1.60 & 2.6 & 0.084 \\
\hline & CS9010 & 2.39 & 9.1 & 0.070 \\
\hline & CS8020 & 2.29 & 10.5 & 0.073 \\
\hline & CS7030 & 2.98 & 10.2 & 0.075 \\
\hline \multirow{4}{*}{$\mathrm{n}=4$} & C & 1.40 & 8.2 & 0.104 \\
\hline & CS9010 & 1.28 & 8.9 & 0.095 \\
\hline & CS8020 & 1.36 & 7.5 & 0.127 \\
\hline & CS7030 & 1.25 & 10.4 & 0.077 \\
\hline \multirow{4}{*}{$\mathrm{n}=9$} & $\mathrm{C}$ & 3.42 & 11.6 & 0.140 \\
\hline & CS9010 & 2.20 & 9.2 & 0.119 \\
\hline & CS8020 & 2.56 & 12.4 & 0.099 \\
\hline & CS7030 & 1.62 & 9.8 & 0.077 \\
\hline
\end{tabular}
lag method) and Permeability coefficient. 


\section{4. 結 語}

キトサンとセリシンの混合膜，エチレングリコールジ グリシジルエーテル (EGDE)およびポリエチレングリコー ルジグリシジルエーテル $(\operatorname{PGDE}(\mathrm{n}=4,9))$ で橋かけした 混合膜を作製し, 膜の表面状態の観察, 吸水比之強伸度 の測定および膜に対するアニオン染料 CI Acid Orange 7の 吸着と透過を測定し, キトサン単独膜および橋かけキト サンの場合と比較・検討した. その結果, 以下の知見を 得た.

（1）キトサン単独膜は水酸化ナトリウム水溶液による処 理後も起伏の少ない平坦な表面であるが，混合膜および 橋かけ混合膜は洗浄前は比較的平坦であるのに対し, ア ルカリ処理後は著しい凹凸が観察された.

（2）キトサン/セリシン混合膜はセリシン混合割合が高く なるにつれ，水酸化ナトリウム水溶液による処理によっ て質量減少率は直線的に増加した，橋かけ混合膜の場合 には，セリシン混合割合が低く(30\%以下), 橋かけ郕の分 子鎖が短い(EGDE, PGDE, $n=4)$ ときには質量減少率は低 く, 吸水比も小さい.一方, より長い分子の橋かけ剤(PGDE, $\mathrm{n}=9$ ) を用いた場合には質量減少率も吸水比も大きい.

（3）セリシンの混合割合が低い場合, 混合膜の伸びは十 分であるが，混合割合が高くなるにしたがって伸びは極 端に小さくなる. 分子鎖の短い橋かけ剤 EGDEによって 橋かけされた混合膜の強度および伸びはキトサン単独膜 に比べ非常に低い. より分子鎖の長い橋かけ剤 $\operatorname{PGDE}(\mathrm{n}=$ 4)を用いた場合は, 強度は増加するが伸びは低下した。

一方, さらに長い分子鎖の橋かけ剤 PGDE (n = 9) で橋か けした混合膜の伸びはキトサン単独膜のそれに匹敵した。

(4) 混合膜中のアニオン染料 CI Acid Orange 7の拡散係数 および透過係数の值は, セリシンを混合することにより 非常に高くなる. $\operatorname{PGDE}(\mathrm{n}=4)$ で橋かけした混合膜の場合 は拡散係数および透過係数が低下寸るが，より分子鎖の 長い PGDE $(n=9)$ で橋かけした混合膜では拡散係数は $\operatorname{PGDE}(\mathrm{n}=4)$ を用いた場合より高くなり，したがって透過 係数もまた高い值となった。
謝 辞

本論文をまとめるにあたり，セリシンを提供して頂い たセーレン侏および橋かけ剤 $\operatorname{PGDE}(\mathrm{n}=4,9)$ を供与して頂 いたナガセケムテックス侏に感謝致します.

\section{文 献}

1. M. Nakajima, I. Fujimasa, K. Imachi, K. Atsumi, and K. Kifune, Jpn. J. Artif. Organs, 14, 868-871 (1985)

2. S. Miyazaki, Chitin Chitosan Res., 7, 1-8 (2001)

3. C. K. Yeom, Y. H. Kim, J. M. Lee, J. Apply. Polm. Sci., 84, 1025-1034 (2002)

4. N. Katoh, S. Satoh, A. Yamanaka, H. Yamada, N. Fuwa, and M. Nomura, Biosci. Biotechnol. Biochem., 62, 145 (1998)

5. N. Katoh and M. Sasaki, Fragrance J., 4, 28 (2000)

6. N. Katoh, presented at 54th Silk Summer Seminar, Okaya, July. 26-27, 2001

7. N. Katoh, A. Shoji, and H. Yamada, Bio Industry, 15, 15 (1998)

8. Haeyong Kweon, Hyun Chul Ha, In Chul Um, Young Hwam Park, J.Apply.Polm.Sci., 80, 928-934 (2001)

9. H. Miyake, H. Wakisaka and M. Nagura, J. Ins. Biotech, 71, 85-89 (2002)

10. H. Miyake, H. Wakisaka, and M. Nagura, Polym. J., 35 (8), 683-687 (2003)

11. G. A. F. Roberts, "Chitin Chemistry", MACMILAN Press, p. 230 (1992)

12. Y. Shimizu, A. Taga and H. Yamaoka, Adsorp. Sci. Technol., 21 (5), 439-449 (2003) 